\title{
In vitro evaluation of dietary compounds to reduce mercury bioavailability
}

Carlos Jadán-Piedra, Dinoraz Vélez, Vicenta Devesa*

Instituto de Agroquímica y Tecnología de Alimentos (IATA-CSIC), Av. Agustín Escardino 7, 46980

Paterna (Valencia), Spain.

* To whom correspondence should be addressed (telephone (+34) 963900 022; fax (+34) 963636

301; e-mail:vdevesa@iata.csic.es) 


\begin{abstract}
Mercury in foods, in inorganic form $[\mathrm{Hg}(\mathrm{II})]$ or as methylmercury $\left(\mathrm{CH}_{3} \mathrm{Hg}\right)$, can have adverse effects. Its elimination from foods is not technologically viable. To reduce human exposure, possible alternatives might be based on reducing its intestinal absorption. This study evaluates the ability of 23 dietary components to reduce the amount of mercury that is absorbed and reaches the bloodstream (bioavailability). We determined their effect on uptake of mercury in Caco-2 cells, a model of intestinal epithelium, exposed to $\mathrm{Hg}(\mathrm{II})$ and $\mathrm{CH}_{3} \mathrm{Hg}$ standards and to swordfish bioaccessible fractions. Cysteine, homocysteine, glutathione, quercetin, albumin and tannic reduce bioavailability of both mercury species. Fe(II), lipoic acid, pectin, epigallocatechin and thiamine are also effective for $\mathrm{Hg}(\mathrm{II})$. Some of these strategies also reduce $\mathrm{Hg}$ bioavailability in swordfish (glutathione, cysteine, homocysteine). Moreover, extracts and supplements rich in these compounds are also effective. This knowledge may help to define dietary strategies to reduce in vivo mercury bioavailability.
\end{abstract}

Keywords: mercury; food; swordfish; bioavailability; dietary strategies 


\section{INTRODUCTION}

Diet is the main source of exposure to mercury $(\mathrm{Hg})$ for the general population. This contaminant is present in foods as methylmercury $\left(\mathrm{CH}_{3} \mathrm{Hg}\right)$ or inorganic mercury $[\mathrm{Hg}(\mathrm{II})]$. It has been reported that tuna, swordfish, cod, whiting, and pike were the major contributors to $\mathrm{CH}_{3} \mathrm{Hg}$ dietary exposure in the adult European population (EFSA, 2012). Some studies link high prenatal exposure to $\mathrm{CH}_{3} \mathrm{Hg}$, as a result of the mother consuming seafood products with elevated levels of this species of mercury, with deficits in neurobehavioral development (Grandjean et al., 2002). Therefore, some public health agencies recommend avoiding or reducing consumption of certain kinds of seafood in susceptible population groups (children, pregnant and breastfeeding women) (Health Canada, 2008). This recommendation should not be associated with a decrease in consumption of seafood for the general population, given the high nutritional value of these food products (EFSA, 2012).

The existing concern has led to investigation of alternatives to reduce $\mathrm{Hg}$ dietary exposure. Methods have been developed to remove $\mathrm{Hg}$ from seafood products before they are marketed by the addition of leaching and chelating agents (Schab et al., 1978; Aizpurúa et al., 1997; Hajeb and Jinap, 2012). The conditions applied (long times, acid pHs, sliced or minced fish) have not made their industrial scale-up advisable. As an alternative, there has been research on the possibility of reducing the amount of $\mathrm{Hg}$ ingested that reaches the systemic circulation. These approaches have concentrated on searching for strategies to reduce the $\mathrm{Hg}$ that is in soluble form after digestion and therefore available for absorption (bioaccessibility). Using a simulated human digestion approach, JadánPiedra et al. (2016a) showed that addition of tannic acid, cellulose, lignin, or pectin during digestion of swordfish and tuna significantly reduces $\mathrm{Hg}$ bioaccessibility (30-98\% reduction). Later studies by the same research group showed that some strains of lactic acid bacteria and of Saccharomyces cerevisiae are also effective in reducing bioaccessibility from foods (Jadán-Piedra et al., 2017a,b).

Another way of pursuing this objective is by acting directly on intestinal absorption. This process is dependent on the physicochemical state of the substance, the lumen environment, the metabolic 
activity and functions of the intestinal cell, and the structure of the absorbing surface (Levine, 1970). The chemical form of $\mathrm{Hg}$ is a determining factor in its absorption. The absorption of $\mathrm{Hg}$ (II) present in food has been reported to be less than $15 \%$ in experimental animals (Piotrowski et al., 1992), and in human volunteers who ingested an oral tracer dose of $\mathrm{Hg}(\mathrm{II})$ nitrate given either in aqueous solution or bound to protein (Rahola et al., 1973). In contrast, about $95 \%$ of the $\mathrm{CH}_{3} \mathrm{Hg}$ in fish ingested by humans, and about $95 \%$ of methylmercuric nitrate given orally to volunteers is absorbed (NRC, 2000). Another decisive factor is the lumen environment; interactions of the element with components of the diet or with intestinal microbiota present in the lumen can play a crucial role in its absorption. In fact, it has been shown that the activity of intestinal bacteria facilitates fecal excretion of $\mathrm{CH}_{3} \mathrm{Hg}$ owing to its demethylation to $\mathrm{Hg}(\mathrm{II})$ (Rowland et al., 1984).

The aim of this study is to seek dietary components capable of reducing the amount of $\mathrm{Hg}$ that is absorbed by the intestinal epithelium (bioavailability) using human colon Caco- 2 cells as a model of the intestinal epithelium.

\section{MATERIALS AND METHODS}

2.1. Bioaccessibility of Food Products. Fillets of swordfish (Xiphias gladius) cooked in a frying pan without additional ingredients were submitted to in vitro gastrointestinal digestion, following the protocol described by Jadán-Piedra et al. (2016b). Five grams of sample were weighed and deionized water was added to make a final volume of $50 \mathrm{~mL}$. The $\mathrm{pH}$ was adjusted to 2.0 with $6 \mathrm{M}$ $\mathrm{HCl}$, and a solution of pepsin $(0.1 \mathrm{~g}$ of pepsin/mL prepared in $0.1 \mathrm{M} \mathrm{HCl})$ was added to obtain 0.01 $\mathrm{g}$ of pepsin/50 $\mathrm{mL}$ of digestion solution. The mixture was incubated at $37{ }^{\circ} \mathrm{C}$ for $2 \mathrm{~h}$ with constant shaking (120 rpm).

The digest was then submitted to the intestinal digestion step. The $\mathrm{pH}$ was increased to 6.5 by means of $\mathrm{NH}_{3} 25 \%$ (Panreac), and a solution of pancreatin and bile extract was added $(0.004 \mathrm{~g} / \mathrm{mL}$ of pancreatin and $0.025 \mathrm{~g} / \mathrm{mL}$ of bile extract in $0.1 \mathrm{M} \mathrm{NH}_{4} \mathrm{HCO}_{3}$ ) to obtain a final concentration of 
$1.25 \mathrm{mg}$ of pancreatin/50 $\mathrm{mL}$ of digestion solution and $7.5 \mathrm{mg}$ of bile extract $/ 50 \mathrm{~mL}$ of digestion solution. The mixture was incubated at $37{ }^{\circ} \mathrm{C}$ for $2 \mathrm{~h}$ with constant shaking (120 rpm). After the digestion, the samples were transferred to tubes and centrifuged ( $10000 \mathrm{rpm}, 4{ }^{\circ} \mathrm{C}, 30 \mathrm{~min}$ ), and the soluble fraction was collected to be used in the study.

The enzymes and bile salts used were purchased from Sigma (Spain): porcine pepsin (enzyme activity $944 \mathrm{U} / \mathrm{mg}$ protein), porcine pancreatin (activity equivalent to $4 \times$ US Pharmacopeia specifications/mg pancreatin), and bile extract (glycine, taurine conjugates, and other bile salts).

2.2. Caco-2 cell culture. Caco- 2 cells were acquired from the European Collection of Cell Cultures (ECACC; number 86010202, UK). Cell maintenance was performed in $75 \mathrm{~cm}^{2}$ flasks, using Dulbecco's Modified Eagle Medium (DMEM) with high glucose (4.5 g/L) and glutamine at pH 7.2. The DMEM was supplemented with $10 \%(\mathrm{v} / \mathrm{v})$ of fetal bovine serum, $1 \%(\mathrm{v} / \mathrm{v})$ non-essential amino acids, $1 \mathrm{mM}$ sodium pyruvate, $10 \mathrm{mM}$ HEPES (N-2-hydroxyethylpiperazine-N'-2-ethanesulfonic acid), $100 \mathrm{U} / \mathrm{mL}$ of penicillin, $0.1 \mathrm{mg} / \mathrm{mL}$ of streptomycin, and $0.0025 \mathrm{mg} / \mathrm{L}$ of amphotericin $\mathrm{B}$ (DMEMc). All reagents used were acquired from Hyclone (Fisher, Spain).

The cells were incubated at $37{ }^{\circ} \mathrm{C}$ in an atmosphere with $95 \%$ relative humidity and $5 \% \mathrm{CO}_{2}$ flow. The medium was changed every $2-3$ days. When the cell monolayer reached $80 \%$ confluence, the cells were detached with a solution of trypsin $(0.5 \mathrm{mg} / \mathrm{mL})$ and EDTA (ethylenediaminetetraacetic acid, $0.2 \mathrm{mg} / \mathrm{mL}$ ) (Hyclone), and reseeded at a density of $1 \times 10^{4}$ cells $/ \mathrm{cm}^{2}$. The cells were used between passages 10 and 25 .

Transport assays were performed in 6-well plates with inserts with a polyester membrane (diameter $24 \mathrm{~mm}$, pore size $0.4 \mu \mathrm{m}$; Transwell ${ }^{\circledR}$, Corning, Cultek, Spain). In this system the Caco-2 cells are seeded on the porous support of the insert which separates the well into two compartments: apical (upper) and basolateral (lower). The cells were seeded at a density of $7.5 \times 10^{4}$ cells $/ \mathrm{cm}^{2}$ and they were supplemented with $1.5 \mathrm{~mL}$ of DMEMc in the apical chamber and $2 \mathrm{~mL}$ of DMEMc in the 
basolateral chamber. The cells were incubated at $37{ }^{\circ} \mathrm{C}, 5 \% \mathrm{CO}_{2}$ and $95 \%$ relative humidity, and the medium was changed every 2-3 days until cell differentiation took place (9 days post seeding).

2.3. Determination of Apparent Permeability Coefficients ( $\left.\mathbf{P}_{\mathbf{a p p}}\right)$ and Cellular Retention. The transport assays were performed using standard solutions of $\mathrm{Hg}(\mathrm{II})$ and $\mathrm{CH}_{3} \mathrm{Hg}$ or the bioaccessible fraction of swordfish. The standard solutions were prepared from $\mathrm{Hg}\left(\mathrm{NO}_{3}\right)_{2}(1000 \mathrm{mg} / \mathrm{L}$, Merck, Spain) and $\mathrm{CH}_{3} \mathrm{HgCl}$ (1000 mg/L, Alfa Aesar, Spain) in Hanks' balanced salt solution medium with $\mathrm{NaCO}_{3}$ (HBSS) (Hyclone) supplemented with $10 \mathrm{mM}$ of HEPES (pH 7.2). The bioaccessible fractions were inactivated for the transport assay by heating for $5 \mathrm{~min}$ at $90{ }^{\circ} \mathrm{C}$ to inhibit sample proteases. Glucose (final concentration $1 \mathrm{~g} / \mathrm{L}$, Sigma) was added to facilitate cell viability. $\mathrm{NaCl}$ (5 $\mathrm{mM}$, Panreac) was used to adjust the osmolarity to $300 \pm 30 \mathrm{mOsm} / \mathrm{kg}$, using a freezing point osmometer (Automatic Micro-Osmometer Type 15 Löser, Löser Messtechnik, Germany).

Bioaccessible fractions or $\mathrm{Hg}$ standards $(1.5 \mathrm{~mL})$ were added to the apical compartment, with or without the dietary components to be assayed (Table S1, supplementary data), and HBSS-HEPES ( $2 \mathrm{~mL}$ ) was added to the basolateral side. At the established times $(45,60,90$, and 120 minutes), aliquots were removed from the basolateral compartment and were replaced by the same volume of HBSS-HEPES. Total Hg was determined in aliquots of the basolateral medium removed at each time and in the apical medium and cell recovered at the end of the experiment.

The apparent permeability coefficients $\left(\mathrm{P}_{\mathrm{app}}\right)$ were calculated by using equation 1 .

$$
P_{a p p}=(d C / d t)\left(V_{r} / A C_{o}\right)(\text { Eq.1) }
$$

where:

$d C / d t$ is the flow $(\mu \mathrm{g} / \mathrm{s})$ determined by the linear slope of the equation that governs the variation in the concentrations of $\mathrm{Hg}$, corrected with dilution, against time.

$V_{r}$ is the volume of the acceptor compartment $(2 \mathrm{~mL})$.

$A$ is the surface occupied by the cell monolayer $\left(4.71 \mathrm{~cm}^{2}\right)$. 
$C_{o}$ is the initial concentration of $\mathrm{Hg}$ in the donor compartment $(0.5 \mathrm{mg} / \mathrm{L}$ for standards $)$.

2.4. Cell Monolayer Integrity. During the transport assays, cell monolayer integrity was evaluated by measuring (a) transepithelial electrical resistance (TEER) at various points in the study, including the start and end of the experiment, (b) the $\mathrm{P}_{\text {app }}$ of the paracellular transport marker Lucifer Yellow (LY, Sigma), (c) the cellular viability at the end of the assay.

To determine the LY $\mathrm{P}_{\mathrm{app}}$, the compound was added at a concentration of $100 \mu \mathrm{M}$ to the apical compartment in all the treatments. The fluorescence of the LY transported to the basolateral side was measured with a fluorescence microplate reader (PolarSTAR OPTIMA, BMG-Labtech, Germany) at excitation/emission wavelengths of $485 / 520 \mathrm{~nm}$. Cell viability was determined by staining with $0.4 \%(\mathrm{v} / \mathrm{v})$ trypan blue (Sigma).

The assays were considered valid if: a) TEER values were not modified by more than $25 \%$ with respect to the initial values; b) the LY $\mathrm{P}_{\text {app }}$ was below $2 \times 10^{-7} \mathrm{~cm} / \mathrm{s}$; c) cellular viability $\geq 80 \%$.

2.5. Determination of Hg. Bioaccessible fractions, media, and cell lysates were placed in a Teflon perfluoroalkoxy (PFA) vessel and treated with $1 \mathrm{~mL}$ of $\mathrm{HNO}_{3}\left(14 \mathrm{M}\right.$, Merck) and $1 \mathrm{~mL}$ of $\mathrm{H}_{2} \mathrm{O}_{2}$ (30\% v/v, Panreac). The Teflon PFA vessel was irradiated at $800 \mathrm{~W}\left(15 \mathrm{~min}\right.$ at $180{ }^{\circ} \mathrm{C}$ ) in a microwave accelerated reaction system (MARS) from CEM (Vertex, Spain). At the end of the digestion program, the digest was placed in a tube and allowed to rest all night to eliminate nitrous vapor. It was then made up to volume $(9-15 \mathrm{~mL})$ with $0.6 \mathrm{M} \mathrm{HCl}$.

For mercury quantification, a cold vapor generation-atomic fluorescence spectrometer (CV-AFS) (PSA 10.025 Millennium Merlin, PS Analytical, UK) was employed. The analytical conditions were the following: reducing agent, $2 \%$ (w/v) $\mathrm{SnCl}_{2}$ (Scharlau, Scharlab, Spain) in $1.8 \mathrm{M} \mathrm{HCl,} 4.5$ $\mathrm{mL} / \mathrm{min}$ flow rate; carrier solution, $0.6 \mathrm{M} \mathrm{HCl}, 9 \mathrm{~mL} / \mathrm{min}$ flow rate; carrier gas, argon $0.3 \mathrm{~L} / \mathrm{min}$ flow rate; dryer gas, air $2.5 \mathrm{~L} / \mathrm{min}$ flow rate; specific $\mathrm{Hg}$ lamp; fixed $254 \mathrm{~nm}$ filter. Quantification 
was carried out against an external calibration curve $(0.1-2 \mathrm{ng} / \mathrm{mL})$. The analytical performance of the equipment used for $\mathrm{Hg}$ quantification was evaluated by analysis of a water certified reference standard (RTC, QCI-049-1) supplied by LGC Standards (Spain) [Hg certified value $=(40.8 \pm 1.19)$ $\mu \mathrm{g} / \mathrm{L}]$. The results obtained in the reference material were in good agreement with the certified values: $(40.2 \pm 1.0) \mu \mathrm{g} / \mathrm{L}$.

In all the assays conducted a mass balance was performed, comparing the $\mathrm{Hg}$ added to the cells initially and the $\mathrm{Hg}$ quantified at the end of the transport assays in the apical and basolateral media and in the cells. The results show recoveries ranging between 85 and $99 \%$.

2.6. Statistical Analysis. All tests were performed at least in triplicate in independent cultures. The results were subjected to statistical analysis by one-factor analysis of variance (ANOVA) with the Tukey HSD post hoc multiple comparison test or using the Student t-test (SigmaPlot version 13.0). Differences were considered significant for $\mathrm{p}<0.05$.

\section{RESULTS}

All the results presented in this section correspond to treatments in which the TEER, LY permeability, and cell viability remained within the ranges considered optimal (section 2.4).

\subsection{Effect of Dietary Components on Apparent Permeability of $\mathrm{Hg}$ in Aqueous Solution}

3.1.1. Effect on apparent permeability of aqueous solutions of $\mathrm{Hg}(\mathrm{II})$. The compounds used to attempt to reduce cellular transport of $\mathrm{Hg}(\mathrm{II})$ were selected on the basis of three criteria: a) the possibility that they would compete for transporters of divalent cations [salts of $\mathrm{Zn}$ and $\mathrm{Fe}(\mathrm{II})$ ]; b) the possibility that they would compete for transporters of amino acids, because it has been reported that $\mathrm{Hg}$ (II) bound to Cys (Cys-S-Hg-S-Cys), one of the major forms of $\mathrm{Hg}$ in biological samples, has a structure similar to that of cystine and therefore it can be transported by transporters of that 
amino acid (Bridges et al., 2004) (methionine, cysteine, phenylalanine, homocysteine, arginine, lysine); c) the possible formation of complexes with $\mathrm{Hg}(\mathrm{II})$, which could lead to modification of its transport (glutathione, albumin, xylan, lipoic acid, DHLA, pectin, cysteine, homocysteine, quercetin, tannic acid).

Figure 1 shows the percentages of the $\mathrm{Hg}(\mathrm{II}) \mathrm{P}_{\text {app }}$ in cells co-exposed to $\mathrm{Hg}(\mathrm{II})$ and the various dietary components with respect to the permeability value obtained in cells treated only with $\mathrm{Hg}(\mathrm{II})$, which was considered the control treatment. For $70 \%$ of the components the $\mathrm{P}_{\text {app }}$ was lower than that of the cells treated only with $\mathrm{Hg}$ (II), showing that they reduce transport of $\mathrm{Hg}$ (II) through the monolayer of intestinal cells. The greatest reductions were produced in the presence of compounds with thiol groups, such as GSH $(97 \pm 3) \%$, homocysteine $(94 \pm 2) \%$, cysteine $(93 \pm 1) \%$, DHLA (89 $\pm 2) \%$, or lipoic acid $(83 \pm 2) \%$. There were also considerable reductions with $\mathrm{Fe}(\mathrm{II})(65 \pm 4 \%)$ and with more complex compounds such as thiamine $(83 \pm 9) \%$, pectin $(78 \pm 2) \%$, quercetin $(73 \pm 1) \%$, epigallocatechin $(64 \pm 8) \%$, and tannic acid $(57 \pm 16) \%$.

Many of the reductions in transport were accompanied by decreases in the intracellular content of $\mathrm{Hg}$ (II) (figure 2), with particularly notable reductions produced by thiolated compounds [GSH $(98 \pm 1) \%$, cysteine $(97 \pm 0.2) \%$, and homocysteine $(94 \pm 1) \%]$.

3.1.2. Effect on the apparent permeability of aqueous solutions of $\mathrm{CH}_{3} \mathrm{Hg}$. The criteria for the selection of the compounds used to reduce the permeability of the organic form were the same as those mentioned earlier for $\mathrm{Hg}(\mathrm{II})$, with the exception of those connected with competition for transporters of divalent cations.

Figure 3 shows the percentages of the $\mathrm{CH}_{3} \mathrm{Hg} \mathrm{P}_{\text {app }}$ in cells treated with $\mathrm{CH}_{3} \mathrm{Hg}$ and the dietary components with respect to cells treated only with this form of mercury. The number of compounds capable of modifying this parameter in the cells treated with $\mathrm{CH}_{3} \mathrm{Hg}$ was much lower than that of the compounds capable of altering this parameter in cells treated with $\mathrm{Hg}$ (II). Of the 21 components 
analyzed, only co-exposures with Cys (20 mg/L), GSH (1 mM), homocysteine (5 mg/L), albumin (20 mg/L), tannic acid (20 mg/L), and quercetin $(5 \mathrm{mg} / \mathrm{L})$ produced significant reductions in permeability with respect to the cells treated only with $\mathrm{CH}_{3} \mathrm{Hg}$. The reductions in the percentages of Papp were: GSH $(94 \pm 10) \%$, Cys $(79 \pm 4) \%$, tannic acid $(45 \pm 6) \%$, homocysteine $(29 \pm 2) \%$, quercetin $(24 \pm 9) \%$, and albumin $(21 \pm 8) \%$.

Reductions in cellular accumulation (figure 4) were produced in those treatments in which permeability was also reduced, as in the case of $\mathrm{Hg}(\mathrm{II})$. The largest decreases were obtained with GSH (98 \pm 0.1$) \%$, Cys $(91 \pm 2) \%$, tannic acid $(30 \pm 6) \%$, albumin $(28 \pm 8) \%$, and homocysteine (27 $\pm 5) \%$.

\subsection{Influence of Dietary Supplements and Plant Extracts on $\mathrm{Hg}(\mathrm{II})$ and $\mathrm{CH}_{3} \mathrm{Hg}$ Apparent}

Permeability. Assays were performed with dietary supplements and plant extracts that contained one of the components that had been successful in reducing the $\mathrm{P}_{\text {app }}$ of the forms of mercury (section 3.1). Accordingly, we evaluated the reduction in absorption of standards of $\mathrm{Hg}(\mathrm{II})$ and $\mathrm{CH}_{3} \mathrm{Hg}$ in the presence of extracts rich in tannic acid and/or epigallocatechin (green tea and grape seeds), and supplements of Cys, GSH, thiamine, and lipoic acid.

Supplements of lipoic acid and thiamine did not produce statistically significant reductions in $\mathrm{Hg}$ (II) and $\mathrm{CH}_{3} \mathrm{Hg}$ permeability (data not shown). The other components were effective in reducing absorption of $\mathrm{Hg}(\mathrm{II})$ (figure 5) [green tea extract (median: 72\%), grape seed extract (median: 66\%), and Cys/GSH supplement (median: 32\%)]. Reductions in $\mathrm{CH}_{3} \mathrm{Hg}$ permeability were only achieved in the presence of Cys/GSH supplement (median: 57\%) and grape extract (median: 32\%) (Figure 5).

Of all the treatments performed with supplements and extracts, only the Cys/GSH supplement significantly reduced the intracellular contents of $\mathrm{Hg}(\mathrm{II})(43-65 \%$, median: $60 \%)$ and $\mathrm{CH}_{3} \mathrm{Hg}(87-$ $87 \%$, median: $86 \%$ ). 


\subsection{Influence of Food Components and Supplements on the Apparent Permeability of $\mathbf{H g}$}

present in Foods. The data obtained in the assays with $\mathrm{Hg}$ standards were used to select the components and supplements or extracts to be assayed with the bioaccessible fraction of swordfish. According to the data in the literature (Cabañero et al., 2007), $\mathrm{CH}_{3} \mathrm{Hg}$ is the major species in swordfish, which is why we used supplements that affect transport of this organic form: GSH, Cys, homocysteine, tannic acid, quercetin, GSH/Cys supplement, and grape seed extract.

Table 1 shows the effect of these components or supplements on the permeability of the $\mathrm{Hg}$ present in the bioaccessible fraction of swordfish. As occurred in the standard solutions, GSH was the most effective component in reducing $\mathrm{P}_{\mathrm{app}}$, followed by cysteine and homocysteine. However, tannic acid and quercetin had no effect. The substantial reduction in transport of $\mathrm{Hg}$ that was produced in the presence of the two dietary supplements assayed (range: 29-80\%) is particularly noteworthy.

\section{DISCUSSION}

The mechanisms involved in intestinal transport of $\mathrm{Hg}$ (II) and $\mathrm{CH}_{3} \mathrm{Hg}$ are different. The movement of $\mathrm{HgCl}_{2}$ is mainly carrier-mediated. Vázquez et al. (2015a) showed that DMT1, a transporter of divalent cations and the main mechanism of intestinal absorption of non-heme Fe, is involved in its transport. As for $\mathrm{CH}_{3} \mathrm{HgCl}$, because of its lipophilic nature it has been postulated that part of the absorption may take place through passive diffusion across the cell (Vázquez et al., 2014). Furthermore, it has been shown that mercury species have a high affinity for thiol groups, and it has been indicated that these species may be the major forms of $\mathrm{Hg}$ in foods, tissues and body fluids (Ballatori and Clarkson, 1985; Harris et al., 2003). Some studies point out that these complexes are transported by transporters of amino acids or transporters of organic anions because they have a structural similarity to the substrates of those transporters (Ballatori, 2002). 
The fact that transport of $\mathrm{Hg}$ is mediated by transporters of nutrients suggests the possibility that its absorption across the intestinal epithelium could be reduced by processes of competition with other components of the diet. Moreover, the use of dietary compounds that form complexes with $\mathrm{Hg}$ may also affect transport by modifying the chemical form in which the metal is present in the lumen. In this study, bearing both possibilities in mind, we conducted assays in cellular models of the intestinal epithelium, using divalent cations or amino acids as possible competitors with the transport of these two species of mercury, and also other dietary compounds that are capable of forming complexes with $\mathrm{Hg}$ or with cations with similar physicochemical characteristics. The results obtained show that inhibition of $\mathrm{CH}_{3} \mathrm{Hg}$ transport is achieved mainly with compounds that have thiol groups in their structure (cysteine, homocysteine, GSH, and albumin), with reductions of as much as $89 \%$ for GSH, and $55 \%$ and $25 \%$ in the presence of tannic acid and quercetin, respectively. The spectrum of compounds that reduce absorption of $\mathrm{Hg}(\mathrm{II})$ is much greater; in addition to compounds with thiol groups, the substantial effect of $\mathrm{Fe}$ salts, tannic acid, quercetin, and thiamine is noteworthy. GSH is also the most effective compound ( $97 \%$ reduction).

The reductions in the permeability of the forms of mercury that were demonstrated with tannic acid and quercetin are probably due to the formation of complexes with low solubility. Quercetin is a food flavonoid that is abundant in onions, tea, tomatoes, and apples (Aherne and O'Brien, 2002), has low solubility in water, and therefore has low intestinal absorption (Cai et al., 2013). This flavonoid forms complexes with a large number of divalent cations through the 5-OH and 4-carbonyl groups, whose stability depends on the metal ion assayed (Liu and Guo, 2015). Although, it has been reported that interaction with metals increases the solubility of this flavonoid, the solubility is still very low. Using concentrations of quercetin similar to those ingested by the population, in this study there was a substantial reduction in transport and cellular retention of $\mathrm{Hg}$ in intestinal cells. Its effect on $\mathrm{Hg}$ has not been studied previously, but possibly the formation of complexes with low solubility may be the main mechanism by which quercetin reduces transport of $\mathrm{Hg}$ across the cell monolayer. 
On the other hand, Lesjak et al. (2014) showed that quercetin reduces intestinal absorption of $\mathrm{Fe}(\mathrm{II})$ by chelation, but that it also acts by reducing expression of ferroportin, a transporter of non-heme $\mathrm{Fe}$ in the basolateral domain of enterocytes. Therefore, in addition to its binding ability, there is also a molecular mechanism that affects the Fe(II) transporter. It cannot be ruled out that a similar effect may have taken place in the present study, given that $\mathrm{Hg}(\mathrm{II})$ uses non-heme Fe transporters in its transport in intestinal cells (Vázquez et al., 2015a). With regard to the effect of tannic acid, a compound that occurs naturally in several beverages and many vegetables (Gülçin et al., 2010), it has a high number of carboxylic groups, potential binding sites for cations. In fact, it has been shown that it binds to $\mathrm{Hg}(\mathrm{II})$ and $\mathrm{CH}_{3} \mathrm{Hg}$ in aqueous solution (Torres et al., 1999); it has even been demonstrated that the solubility of the forms of mercury is reduced in the presence of tannic acid at concentrations similar to those used in this study (Jadán-Piedra et al., 2016a).

Another mechanism for reducing $\mathrm{Hg}$ permeability may be connected with the formation of soluble complexes whose transport is less than that of the saline forms of the mercury species. This may be the case with compounds that have thiol groups, such as cysteine, homocysteine, albumin, and GSH. Several studies suggest that the forms of $\mathrm{Hg}$ conjugated with thiol groups are the forms mainly transported through various tissues (Zalups, 2000; Ballatori, 2002), possibly because they are considered to be the most abundant forms in the systemic circulation. However, the data on the magnitude of the transport of Cys/Hg complexes are contradictory. Vázquez et al. $(2014,2015 b)$ showed that in the presence of derivatives of cysteine the transport of $\mathrm{HgCl}$ and $\mathrm{CH}_{3} \mathrm{HgCl}$ is significantly reduced. Endo et al. (1991) demonstrated a substantial reduction of intestinal absorption of $\mathrm{Hg}$ in the presence of Cys in in situ assays. However, in oral exposure of rats to $\mathrm{CH}_{3} \mathrm{HgCl}$ or $\mathrm{CH}_{3} \mathrm{Hg}$-Cys, Mori et al. (2012) did not observe differences in plasma concentrations of $\mathrm{Hg}$. Similarly, in another in vivo study, Roos et al. (2010) observed greater accumulation of the metal in liver and brain of mice treated with $\mathrm{CH}_{3} \mathrm{Hg}$-Cys and greater renal accumulation in the groups treated with $\mathrm{CH}_{3} \mathrm{HgCl}$. For $\mathrm{CH}_{3} \mathrm{Hg}$, the formation of complexes with Cys involves a change 
in the degree of lipophilicity and possibly a change in the transport pathway, from passive diffusion (Vázquez et al., 2014) to carrier-mediated transport (Ballatori, 2002), which might lead to less transport because of the existence of a transport mechanism subject to possible competition and saturation.

The reduction in $\mathrm{Hg}(\mathrm{II})$ permeability produced by ferric salts is possibly a result of competition for the same transport mechanisms. The main transporter of non-heme Fe present in the apical domain of human enterocytes is DMT1. This transporter has affinity for a series of metal cations, including $\mathrm{Hg}$ (II) (Vázquez et al., 2015a). Therefore the presence of Fe(II) salts in concentrations much higher than those of $\mathrm{Hg}(\mathrm{II})$ may lead to a reduction in transport of the toxic metal as a result of competition. This effect on $\mathrm{Hg}(\mathrm{II})$ permeability has also been shown in the presence of $\mathrm{Mn}$ (II) (Vázquez et al., 2015b), another substrate that has high affinity for DMT1 (Garrick et al., 2006). However, the effect does not appear when $\mathrm{Zn}(\mathrm{II})$ is added to the medium. It must be emphasized that $\mathrm{Zn}$ may also be a substrate of DMT1, although this transporter has less affinity for Zn(II) than for $\mathrm{Fe}(\mathrm{II})$ or $\mathrm{Mn}$ (II) (Garrick et al., 2006; Espinoza et al., 2012); in fact, $\mathrm{Zn}$ is transported in the intestine mainly by zrt- and irt-like proteins (ZIP) (Ford, 2004). This may be the cause of the lack of effect of $\mathrm{Zn}$ sulphate on intestinal transport of $\mathrm{Hg}(\mathrm{II})$ observed in the present study.

Irrespective of the mechanism involved in modifying the permeability of the forms of mercury, in the present study we have found compounds that are capable of reducing the bioavailability of $\mathrm{Hg}$ and that also have the advantage of forming part of foods, so their use as strategies to reduce exposure to this metal should not pose any risk. It should be noted that the supplements rich in some of these compounds that were assayed in this study (Cys/GSH supplement and grape seed extract) and that have high effectiveness (32-72\%) are authorized for sale, which makes their use as a dietary strategy more viable. Moreover, it was seen that they are effective not only in aqueous solutions but also in the presence of foods, matrices with greater complexity, in which the nutrients present might cause the metal/dietary strategy interactions to vary. 
Finally, it must be emphasized that most of the compounds that are effective in reducing $\mathrm{Hg}$ permeability in intestinal cells are compounds with a high antioxidant capacity, which may counteract the stress generated by Hg. In vivo studies have shown that administration of quercetin (5-50 mg/kg body weight/day) reduces the stress generated by $\mathrm{CH}_{3} \mathrm{Hg}(30 \mu \mathrm{g} / \mathrm{kg}$ body weight/day, for 45 days), with recovery of levels of GSH and glutathione peroxidase activity (GPx) in exposed rats (Barcelos et al., 2011). The antioxidant effect of tannic acid has been shown in in vivo studies in which the animals were exposed to $\mathrm{Cd}$ and $\mathrm{Pb}$ (Mishra et al., 2015; Tüzmen et al., 2015), metals whose toxicity mechanisms are similar to those described for the forms of mercury.

The data obtained in the present study show that dietary consumption of compounds with thiol groups, flavonoids such as quercetin, polyphenols such as tannic acid, or plant extracts or supplements rich in them may be a suitable strategy to reduce oral bioavailability of $\mathrm{Hg}$. It is necessary to evaluate whether this effect observed in vitro is confirmed in vivo, when the compounds present in the lumen, the activity of the intestinal microbiota, and the metabolism of intestinal cells may alter the interactions observed in the in vitro model.

The compounds assayed should not be harmful, because at the concentrations employed in the present study they form part of a normal diet; however, before proposing their use as dietary strategies for reducing absorption of $\mathrm{Hg}$ it is necessary to verify that their application in vivo does not produce adverse effects. It has been seen that some of these compounds may interfere with absorption of minerals. Reductions in absorption of $\mathrm{Fe}(\mathrm{II})$ in rodents have been reported in the presence of quercetin (Lesjak et al., 2014) and tannic acid (Afsana et al., 2004). A reduction in absorption of essential elements is not desirable if we bear in mind that this kind of strategy may be employed in future population interventions.

\section{ACKNOWLEDGMENTS}


This work was supported by the Spanish Ministry of Economy and Competitiveness (AGL201568920), for which the authors are deeply indebted. Carlos Jadán Piedra received a Personnel Training Grant from SENESCYT (Ecuadorian Ministry of Higher Education, Science, Technology and Innovation) to carry out this study.

\section{REFERENCES}

Afsana, K., Shiga, K., Ishizuka, S., \& Hara, H. (2004). Reducing effect of ingesting tannic acid on the absorption of iron, but not of zinc, copper and manganese by rats. Bioscience, Biotechnology, and Biochemistry, 68, 584-592.

Aherne, S. A., \& O’Brien, N. M. (2002). Dietary flavonols: chemistry, food content, and metabolism. Nutrition, 18, 75-81.

Aizpurúa, I. C. M., Tenuta-Filho, A., Sakuma, A. M., \& Zenebon, O. (1997). Use of cysteine to remove mercury from shark muscle. International Journal of Food Science \& Technology, 32, $333-337$.

Ballatori, N. (2002). Transport of toxic metals by molecular mimicry. Environmental Health Perspectives, 110, 689-694.

Ballatori, N., \& Clarkson, T. W. (1985). Biliary secretion of glutathione and of glutathione-metal complexes. Fundamental and Applied Toxicology, 5, 816-831.

Barcelos, G. R., Grotto, D., Serpeloni, J. M., Angeli, J. P., Rocha, B. A., de Oliveira Souza, V. C., Vicentini, J. T., Emanuelli, T., Bastos, J. K., Antunes, L. M., Knasmüller, S., \& Barbosa. F. Jr. (2011). Protective properties of quercetin against DNA damage and oxidative stress induced by methylmercury in rats. Archives of Toxicology, 85, 1151-1157.

Bridges, C. C., Bauch, C., Verrey, F., \& Zalups, R. K. (2004). Mercuric conjugates of cysteine are transported by the amino acid transporter system $b(0,+)$ : implications of molecular mimicry. Journal of the American Society of Nephrology, 15, 663-673. 
Cabañero, A. I., Madrid, Y., \& Cámara, C. (2007). Mercury-selenium species ratio in representative fish samples and their bioaccessibility by an in vitro digestion method. Biological Trace Element Research, 119, 195-211.

Cai, X., Fang, Z., Dou, J., Yu, A., \& Zhai, G. (2013). Bioavailability of quercetin: problems and promises. Current Medicinal Chemistry, 20, 2572-2582.

EFSA, European Food Safety Authority. (2012). Panel on Contaminants in the Food Chain (CONTAM). Scientific Opinion on the risk for public health related to the presence of mercury and methylmercury in food. EFSA Journal, 10, 2985.

Endo, T., Nakaya, S., \& Kimura, R. (1991). Mechanisms of absorption of inorganic mercury from rat small intestine. IV: Effect of chelating agents and cysteine on absorption of mercuric chloride in situ and in vitro. Basic \& Clinical Pharmacology \& Toxicology, 68, 171-176.

Espinoza, A., Le Blanc, S., Olivares, M., Pizarro, F., Ruz, M., \& Arredondo, M. (2012). Iron, copper, and zinc transport: inhibition of divalent metal transporter 1 (DMT1) and human copper transporter 1 (hCTR1) by shRNA. Biological Trace Element Research, 146, 281-286.

Ford, D. (2004). Intestinal and placental zinc transport pathways. Proceedings of the Nutrition Society, 63, 21-29.

Garrick, M. D., Singleton, S. T., Vargas, F., Kuo, H. C., Zhao, L., Knöpfel, M., Davidson, T., Costa, M., Paradkar, P., Roth, J. A., \& Garrick, L. M. (2006). DMT1: which metals does it transport? Biological Research, 39, 79-85.

Grandjean, P., White, R. F., Weihe, P., \& Jørgensen, P. J. (2002). Neurotoxic risk caused by stable and variable exposure to methylmercury from seafood. Ambulatory Pediatrics. 3, 18-23.

Gülçin, I., Huyut, Z., Elmastaş, M., \& Aboul-Eneind, H. Y. (2010). Radical scavenging and antioxidant activity of tannic acid. Arabian Journal of Chemistry, 3, 43-53. 
Hajeb, P., \& Jinap, S. (2012). Reduction of mercury from mackerel fillet using combined solution of cysteine, EDTA, and sodium chloride. Journal of Agricultural and Food Chemistry, 60, 60696076.

Harris, H. H., Pickering, I. J., \& George, G. N. (2003). The chemical form of mercury in fish. Science, 301, 1203.

Health Canada. Mercury in Fish: Consumption Advice: Making Informed Decisions about Fish. (2008). http://www.hc-sc.gc.ca/fn-an/securit/chem-chim/environ/mercur/cons-adv-etud-eng.php. Accessed 13 July 2017.

Jadán-Piedra, C., Sánchez, V., Vélez, D., \& Devesa, V. (2016a). Reduction of mercury bioaccessibility using dietary strategies. LWT - Food Science and Technology, 71, 10-16.

Jadán-Piedra, C., Clemente, M. J., Devesa, V., \& Vélez, D. (2016b). Influence of physiological gastrointestinal parameters on the bioaccessibility of mercury and selenium from swordfish. Journal of Agricultural and Food Chemistry, 64, 690-698.

Jadán-Piedra, C., Alcántara, C., Monedero, V., Zúñiga, M., Vélez, D., \& Devesa, V. (2017a). The use of lactic acid bacteria to reduce mercury bioaccessibility. Food Chemistry, 228, 158-166.

Jadán-Piedra, C., Baquedano, M., Puig, S., Vélez, D., \& Devesa, V. (2017b). Use of Saccharomyces cerevisiae to reduce the bioaccessibility of mercury from food. Journal of Agricultural and Food Chemistry, 65, 2876-2882.

Lesjak, M., Hoque, R., Balesaria, S., Skinner, V., Debnam, E. S., Srai, S. K., \& Sharp, P. A. (2014). Quercetin inhibits intestinal iron absorption and ferroportin transporter expression in vivo and in vitro. PLoS One, 9, e102900.

Levine, R. R. (1970). Factors affecting gastrointestinal absorption of drugs. American Journal of Digestive Diseases, 15, 171-188.

Liu, Y., \& Guo, M. (2015). Studies on transition metal-quercetin complexes using electrospray ionization tandem mass spectrometry. Molecules, 20, 8583-8594. 
Mishra, S., Ghosh, D., Dutta, M., Chattopadhyay, A., \& Bandyopadhyay, D. (2015). Tannic acid protects against cadmium-induced renal damages of male albino rats. International Journal of Pharmaceutical Sciences Review and Research, 32, 273-281.

Mori, N., Yamamoto, M., Tsukada, E., Yokooji, T., Matsumura, N., Sasaki, M., \& Murakami, T. (2012). Comparison of in vivo with in vitro pharmacokinetics of mercury between methylmercury chloride and methylmercury cysteine using rats and $\mathrm{Caco} 2$ cells. Archives of Environmental Contamination and Toxicology, 63, 628-636.

NRC, National Research Council. (2000). Toxicological effects of methylmercury. Washington, D.C.: Ed. National Academy Press.

Piotrowski, J. K., Szymanska, J. A., Skrzypinska-Gawrysiak, M., Kotelo, J., \& Sporny, S. (1992). Intestinal absorption of inorganic mercury in rat. Basic \& Clinical Pharmacology \& Toxicology, $70,53-55$.

Rahola, T., Hattula, T., Korolainen, A., \& Miettinen, J. K. (1973). Elimination of free and proteinbound ionic mercury $\left({ }^{203} \mathrm{Hg} 2+\right)$ in man. Annals of Clinical Research, 5, 214-219.

Roos, D. H., Puntel, R. L., Lugokenski, T. H., Ineu, R. P., Bohrer, D., Burger, M. E., Franco, J. L., Farina, M., Aschner, M., Rocha, J. B., \& de Vargas Barbosa, N. B. (2010). Complex methylmercury-cysteine alters mercury accumulation in different tissues of mice. Basic \& Clinical Pharmacology \& Toxicology, 107, 789-792.

Rowland, I. R., Robinson, R. D., \& Doherty, R. A. (1984). Effects of diet on mercury metabolism and excretion in mice given methylmercury: role of gut flora. Archives of Environmental Health, $39,401-408$.

Schab, R., Sachs, K., \& Yannai, S. A. (1978). Proposed industrial method for the removal of mercury from fish. Journal of the Science of Food and Agriculture, 29, 274-280. 
Torres, J., Olivares, S., De la Rosa, D., Lima, L., Martínez, F., Munita, C., \& Favaro, D. (1999). Removal of mercury(II) and methylmercury from solution by tannin adsorbents. Journal of Radioanalytical and Nuclear Chemistry, 240, 361-365.

Tüzmen, M. N., Yücel, N. C., Kalburcu, T., \& Demiryas, N. (2015). Effects of curcumin and tannic acid on the aluminum- and lead-induced oxidative neurotoxicity and alterations in NMDA receptors. Toxicology Mechanisms and Methods, 25, 120-127.

Vázquez, M., Vélez, D., \& Devesa, V. (2014). In vitro characterization of the intestinal absorption of methylmercury using a Caco-2 cell model. Chemical Research in Toxicology, 27, 254-264.

Vázquez, M., Vélez, D., Devesa, V., \& Puig, S. (2015a). Participation of divalent cation transporter DMT1 in the uptake of inorganic mercury. Toxicology, 331, 119-124.

Vázquez, M., Devesa, V., \& Vélez, D. (2015b). Characterization of the intestinal absorption of inorganic mercury in Caco-2 cells. Toxicology in Vitro, 29, 93-102.

Zalups, R. K. (2000). Molecular interactions with mercury in the kidney. Pharmacological Reviews, $52,113-143$.

\section{FIGURE CAPTIONS}

Figure 1. Effect of dietary components on transport of $\mathrm{Hg}(\mathrm{II})$. Bars represent apparent permeability coefficients ( $\left.\mathrm{P}_{\mathrm{app}}\right)$ of Caco-2 cells co-exposed to $\mathrm{Hg}(\mathrm{II})(0.5 \mathrm{mg} / \mathrm{L})$ and various food components for $2 \mathrm{~h}$. Values expressed as percentages with respect to cells treated only with $\mathrm{Hg}(\mathrm{II})$ (mean $\pm \mathrm{SD}, \mathrm{n}=$ 3). Asterisks indicate statistically significant reductions with respect to the treatments only with $\operatorname{Hg}(\mathrm{II})(\mathrm{p}<0.05)$.

Figure 2. Effect of dietary components on cellular retention of $\mathrm{Hg}(\mathrm{II})$. Bars represent intracellular contents in Caco-2 cells co-exposed to $\mathrm{Hg}$ (II) $(0.5 \mathrm{mg} / \mathrm{L})$ and various dietary components for $2 \mathrm{~h}$. Values expressed as percentages with respect to cells treated only with $\mathrm{Hg}(\mathrm{II})$ (mean $\pm \mathrm{SD}, \mathrm{n}=3$ ). Only those components that produced statistically significant reductions are shown $(\mathrm{p}<0.05)$. 
Figure 3. Effect of dietary components on transport of $\mathrm{CH}_{3} \mathrm{Hg}$. Bars represent apparent permeability coefficients $\left(\mathrm{P}_{\mathrm{app}}\right)$ of Caco-2 cells co-exposed to $\mathrm{CH}_{3} \mathrm{Hg}(0.5 \mathrm{mg} / \mathrm{L})$ and various dietary components for $2 \mathrm{~h}$. Values expressed as percentages with respect to cells treated only with $\mathrm{CH}_{3} \mathrm{Hg}$ (mean $\pm \mathrm{SD}$, $\mathrm{n}=3$ ). Asterisks indicate statistically significant differences with respect to the treatments only with $\mathrm{CH}_{3} \mathrm{Hg}(\mathrm{p}<0.05)$.

Figure 4. Effect of dietary components on cellular retention of $\mathrm{CH}_{3} \mathrm{Hg}$. Bars represent intracellular contents in Caco-2 cells co-exposed to $\mathrm{CH}_{3} \mathrm{Hg}(0.5 \mathrm{mg} / \mathrm{L})$ and various dietary components for $2 \mathrm{~h}$. Values expressed as percentages with respect to cells treated only with $\mathrm{CH}_{3} \mathrm{Hg}$ (mean $\pm \mathrm{SD}, \mathrm{n}=3$ ). Only those components that produced statistically significant reductions are shown $(\mathrm{p}<0.05)$.

Figure 5. Effect of dietary supplements or plant extracts on transport of $\mathrm{Hg}(\mathrm{II})$ and $\mathrm{CH}_{3} \mathrm{Hg}$. Bars represent percentages of reduction in apparent permeability coefficients $\left(\mathrm{P}_{\mathrm{app}}\right)$ in Caco-2 cells coexposed for $2 \mathrm{~h}$ to $\mathrm{Hg}(\mathrm{II})$ or $\mathrm{CH}_{3} \mathrm{Hg}$ (both $0.5 \mathrm{mg} / \mathrm{L}$ ) and various plant extracts or dietary supplements. Values expressed as percentages with respect to cells treated only with $\mathrm{Hg}$ (mean \pm $\mathrm{SD}, \mathrm{n}=3$ ). Asterisks indicate statistically significant differences with respect to the values obtained in cells treated only with $\mathrm{Hg}$ standards $(\mathrm{p}<0.05)$. 
Table S1. Dietary compounds used in the study.

\begin{tabular}{|c|c|c|c|}
\hline Dietary compounds & $\begin{array}{c}\text { Concentration } \\
\text { (aqueous standards) }\end{array}$ & $\begin{array}{c}\text { Concentration (food } \\
\text { matrix) }\end{array}$ & Brand \\
\hline Bovine serum albumin & $20 \mathrm{mg} / \mathrm{L}$ & n.a. & Biowest \\
\hline Catechin monohydrate & $5 \mathrm{mg} / \mathrm{L}$ & n.a. & Fluka \\
\hline Corn starch dextrin & $10 \mathrm{mg} / \mathrm{L}$ & n.a. & Sigma \\
\hline DL-Homocysteine (HCys) & $5 \mathrm{mg} / \mathrm{L}$ & $5 \mathrm{mg} / \mathrm{L}$ & Sigma \\
\hline Epigallocatechin & $5 \mathrm{mg} / \mathrm{L}$ & n.a. & Sigma \\
\hline Glutathione (GSH) & $1 \mathrm{mM}$ & $1 \mathrm{mM}$ & Sigma \\
\hline Iron(II) sulfate [Fe(II)] & $50 \mathrm{mg} / \mathrm{L}$ & n.a. & Sigma \\
\hline L-Arginine (Arg) & $20 \mathrm{mg} / \mathrm{L}$ & n.a. & Sigma \\
\hline Lecithin (granular) & $10 \mathrm{mg} / \mathrm{L}$ & n.a. & Sigma \\
\hline$( \pm)$ - $\alpha$-Lipoic acid & $10 \mathrm{mg} / \mathrm{L}$ & n.a. & Sigma \\
\hline Reduced lipoic acid (DHLA) & $50 \mathrm{mg} / \mathrm{L}$ & n.a. & Sigma \\
\hline L-Methionine (Met) & $20 \mathrm{mg} / \mathrm{L}$ & n.a. & Merck \\
\hline L-Phenylalanine (Phe) & $20 \mathrm{mg} / \mathrm{L}$ & n.a. & Merck \\
\hline Lysine monohydrate (Lys) & $20 \mathrm{mg} / \mathrm{L}$ & n.a. & Merck \\
\hline Lys + Phe & $20 \mathrm{mg} / \mathrm{L}+20 \mathrm{mg} / \mathrm{L}$ & n.a. & Merck \\
\hline Pectin (from apple) & $50 \mathrm{mg} / \mathrm{L}$ & n.a. & Sigma \\
\hline Quercetin dihydrate & $5 \mathrm{mg} / \mathrm{L}$ & $5 \mathrm{mg} / \mathrm{L}$ & Sigma \\
\hline Selenium dioxide $[\mathrm{Se}(\mathrm{IV})]$ & $0.5 \mathrm{mg} / \mathrm{L}$ & n.a. & Merck \\
\hline Tannic acid & $20 \mathrm{mg} / \mathrm{L}$ & $20 \mathrm{mg} / \mathrm{L}$ & Merck \\
\hline Thiamine hydrochloride & $25 \mathrm{mg} / \mathrm{L}$ & n.a. & Sigma \\
\hline Xylan (from oat flakes) & $20 \mathrm{mg} / \mathrm{L}$ & n.a. & Sigma \\
\hline Zinc sulfate $[\mathrm{Zn}(\mathrm{II})]$ & $50 \mathrm{mg} / \mathrm{L}$ & n.a. & Panreac \\
\hline \multicolumn{4}{|c|}{ Dietary supplements or extracts } \\
\hline Benfotiamine supplement & $100 \mathrm{mg} / \mathrm{L}$ & n.a. & Life Extension \\
\hline Grape seed extract & $100 \mathrm{mg} / \mathrm{L}$ & $100 \mathrm{mg} / \mathrm{L}$ & Plantextrakt \\
\hline Green tea extract & $100 \mathrm{mg} / \mathrm{L}$ & n.a. & Plantextrakt \\
\hline GSH/Cys/vitamin C & $100 \mathrm{mg} / \mathrm{L}$ & $100 \mathrm{mg} / \mathrm{L}$ & Life Extension \\
\hline Lipoic acid supplement & $100 \mathrm{mg} / \mathrm{L}$ & n.a. & Life Extension \\
\hline
\end{tabular}

n.a.: not assayed. 
Table 1. Effect of the dietary strategies (food compounds, dietary supplements, plant extracts) on the transport of $\mathrm{Hg}$ present in the bioaccessible fraction of swordfish. Apparent permeability coefficients $\left(\mathrm{P}_{\text {app }}\right)$ of the Caco-2 monolayers exposed for 120 min to the bioaccessible fractions in the presence or absence of the dietary strategies, and reduction in $\mathrm{Hg} \mathrm{P}_{\text {app }}$ in the presence of those compounds (mean $\pm \mathrm{SD} ; \mathrm{n}=4-6$ ). Asterisks indicate statistically significant differences in the $\mathrm{P}_{\mathrm{app}}$ values with respect to the assays performed without dietary strategy $(\mathrm{p}<0.05)$.

\begin{tabular}{|c|c|c|}
\hline & $P_{\text {app }}\left(\times 10^{-5} \mathrm{~cm} / \mathrm{s}\right)$ & $P_{\text {app }}$ reduction $(\%)$ \\
\hline \multicolumn{3}{|l|}{ Food components } \\
\hline Without component & $1.39 \pm 0.40$ & \\
\hline Cysteine & $0.87 \pm 0.14$ & $37.5 \pm 10.0 *$ \\
\hline GSH & $0.65 \pm 0.37$ & $53.7 \pm 21.7 *$ \\
\hline Homocysteine & $0.91 \pm 0.13$ & $34.6 \pm 9.6^{*}$ \\
\hline Tannic acid & $1.92 \pm 0.81$ & - \\
\hline Quercetin & $1.50 \pm 0.40$ & - \\
\hline \multicolumn{3}{|l|}{ Supplements or extracts } \\
\hline Without component & $3.69 \pm 0.41$ & \\
\hline Cys/GSH supplement & $2.50 \pm 0.34$ & $37.0 \pm 10.6^{*}$ \\
\hline Grape seed extract & $1.64 \pm 0.82$ & $63.8 \pm 22.6^{*}$ \\
\hline
\end{tabular}


Figure 1

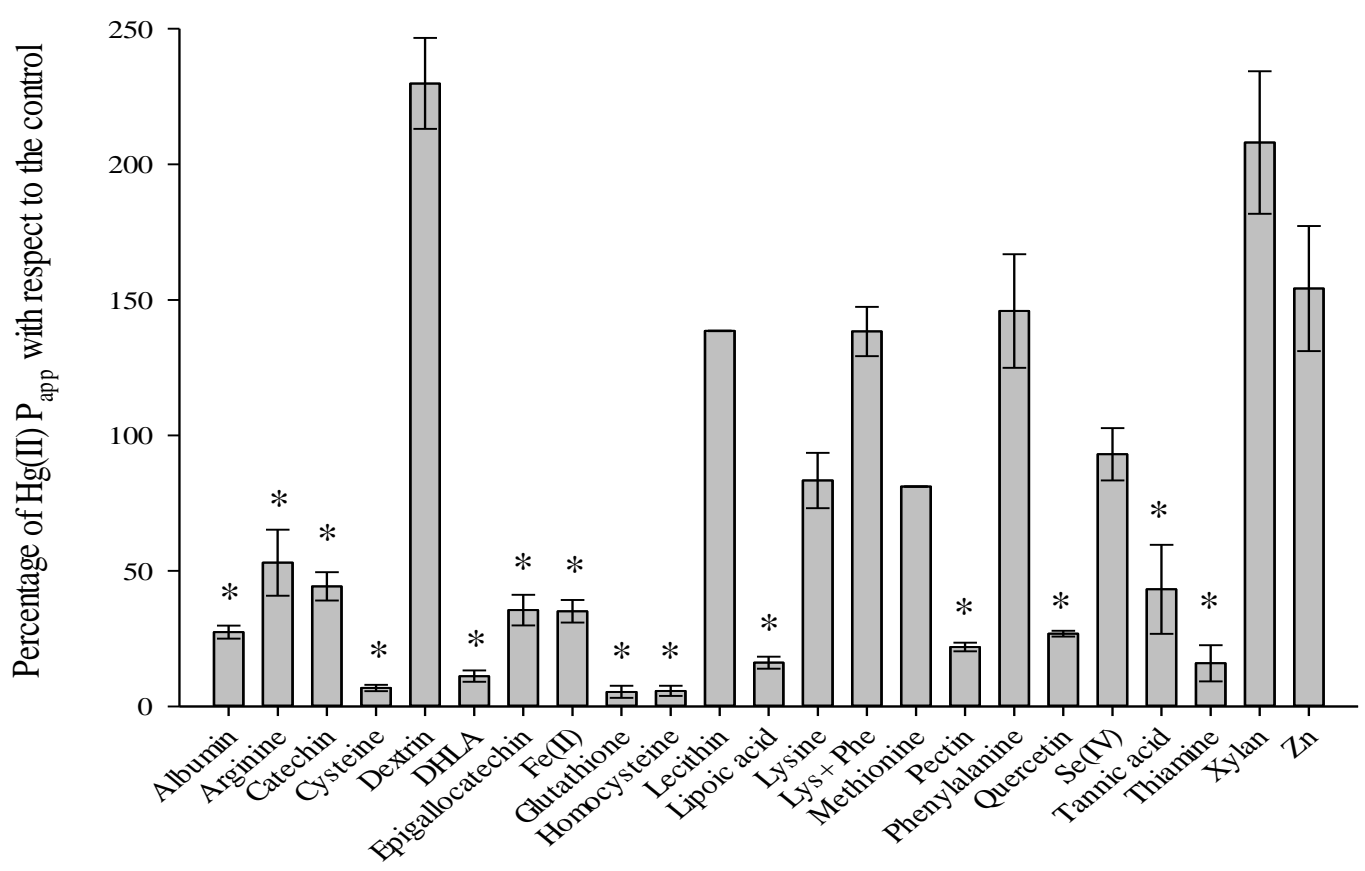


Figure 2.

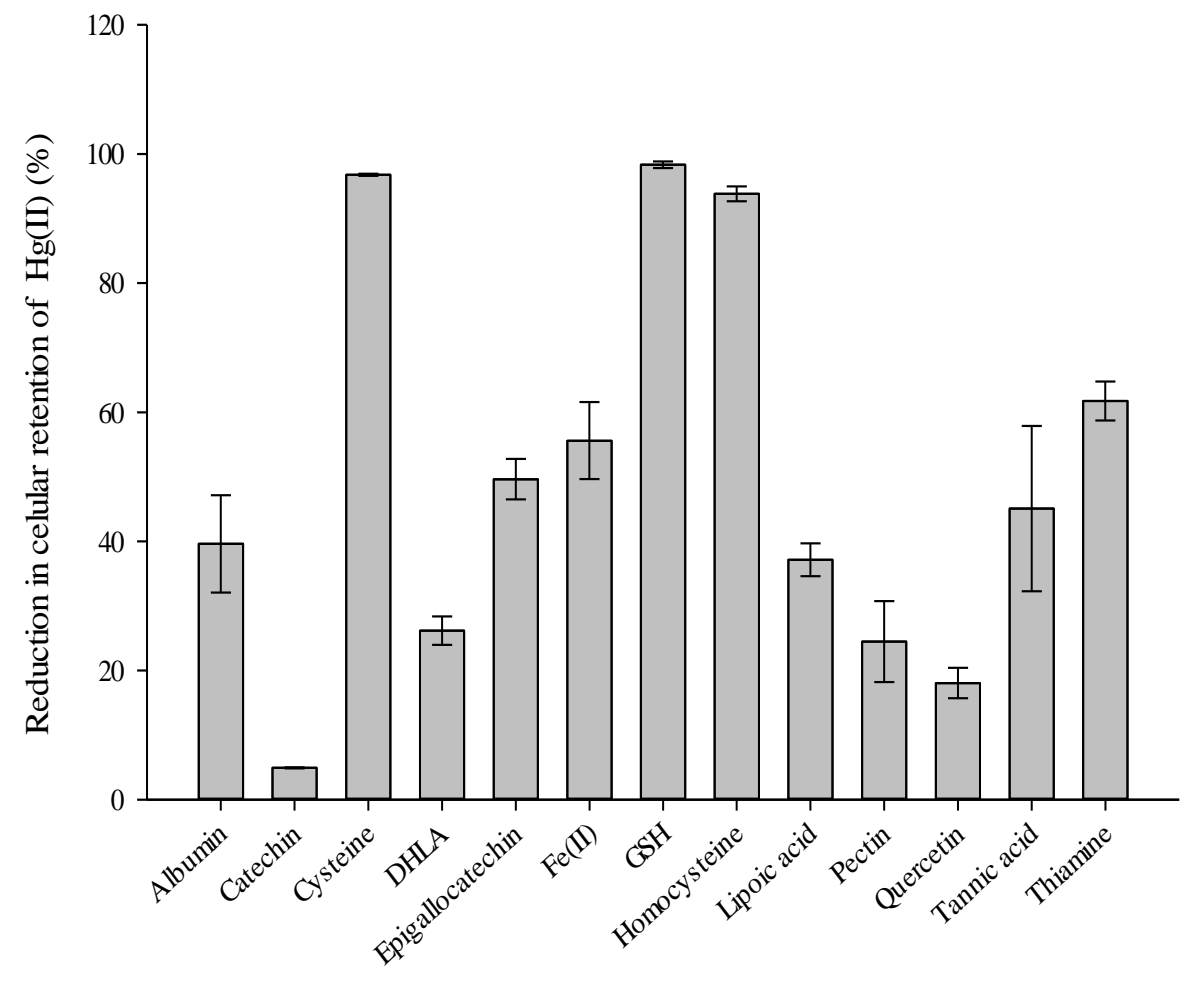


Figure 3.

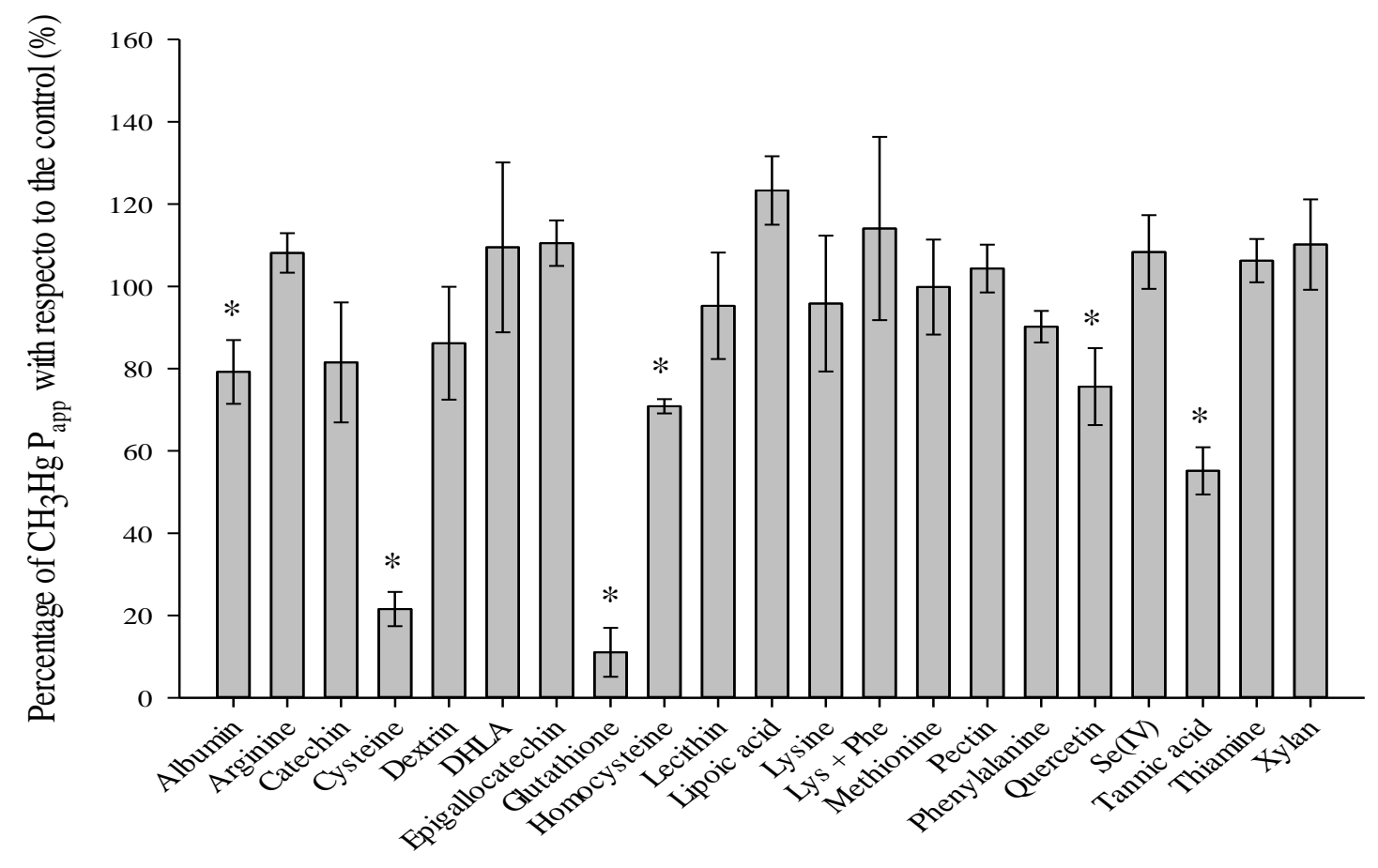


Figure 4.

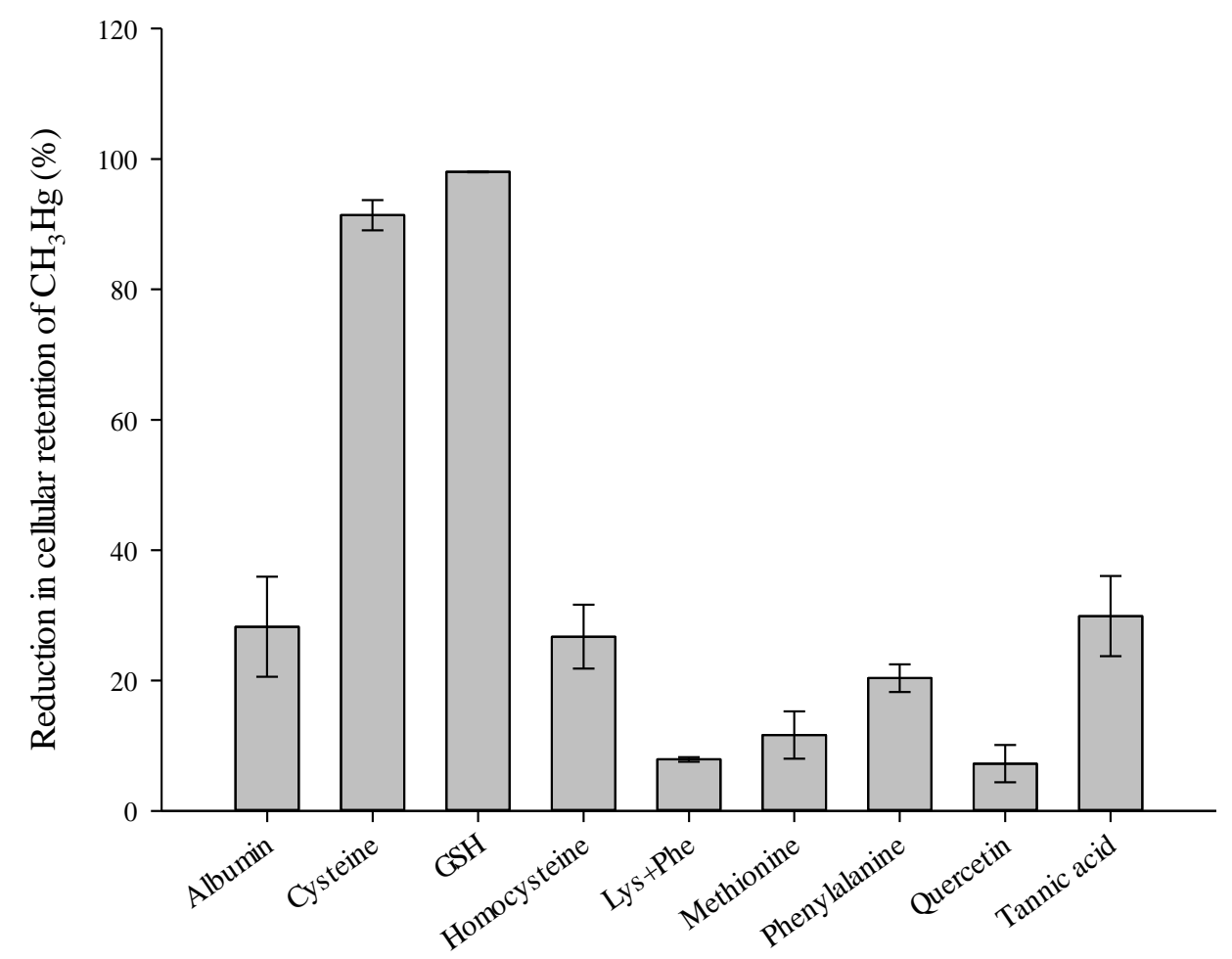


Figure 5.

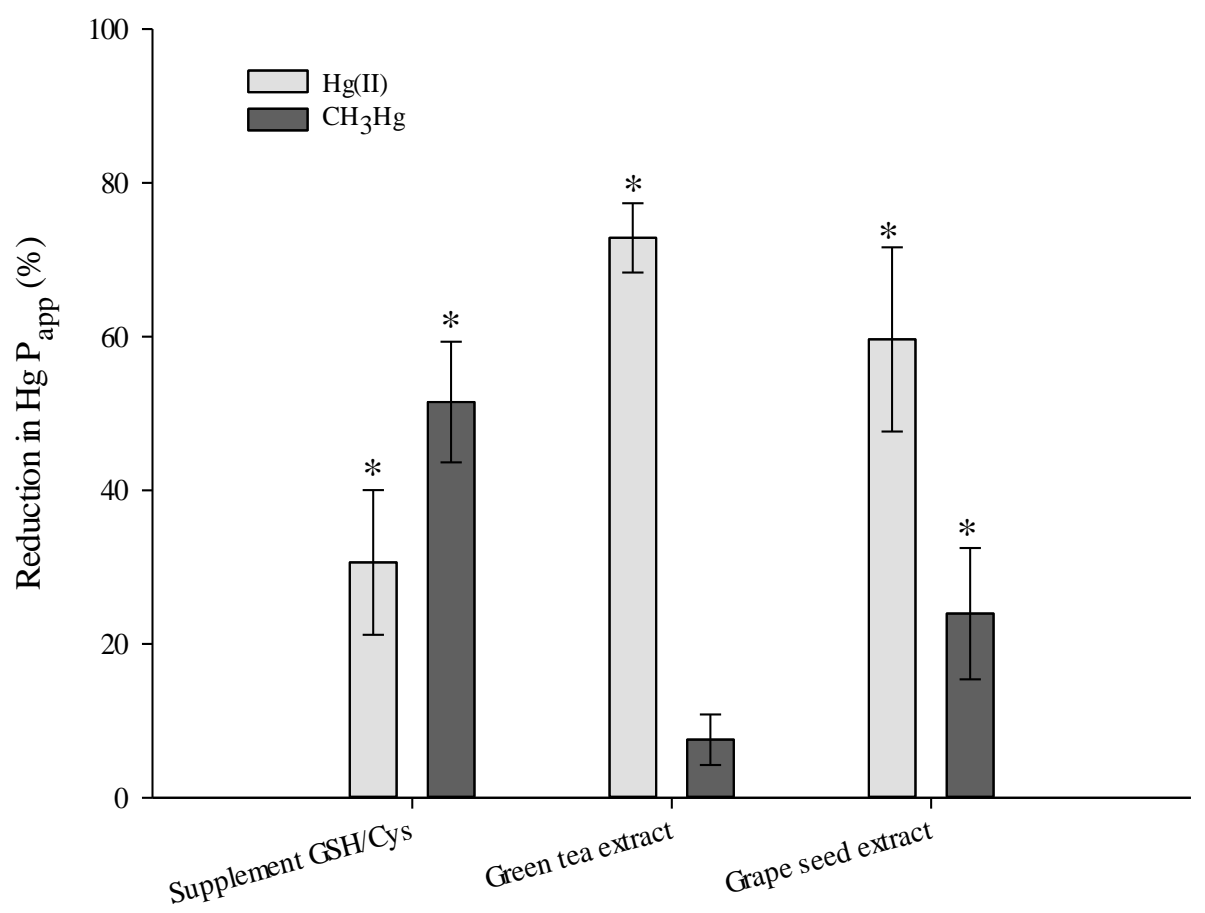

